\title{
A VENDA DE COISA ALHEIA COMO PRÓPRIA, EM PORTUGAL
}

\author{
THE PORTUGUESE ACQUISITION OF A THIRD PARTY'S GOOD AS YOUR OWN
}

\begin{abstract}
Mónica Vanderleia Alves de Souza Jardim Doutora em Ciências Jurídico-Civilísticas (Direito das Coisas/Direito do Registo Predial) Mestre em Ciências Jurídico-Empresariais pela Universidade de Coimbra. Professora Assistente da Faculdade de Direito da Universidade de Coimbra. Faculdade de Direito da Universidade de Coimbra (FDUC) Coimbra, Portugal mvasjardim@gmail.com
\end{abstract}

Resumo: Através do presente estudo, começamos por apresentar uma nota prévia sobre a venda de coisa alheia como própria, em Portugal. De seguida, analisamos criticamente e refutamos a tese segundo a qual a venda de bens alheios é válida, embora resolúvel, bem como a tese segundo a qual a venda de coisa alheia como própria é, apenas, parcialmente nula. Concluímos, afirmando que a venda de coisa alheia, não obstante estar sujeita a um regime atípico, é totalmente nula.

Palavras-chave: Direito civil. Nulidade. Venda coisa alheia.

Abstract: Through this study, we begin by presenting a preliminary note on the acquisition of a third party`s good as your own in Portugal. Then, we critically analyze and refute the thesis according to which this sort of acquisition is valid, although resolvable, as well as the other thesis by which this institute is only partially null. We conclude by stating that the acquisition of a third party`s good, despite being subject to an atypical regime, is totally null.

Keywords: Civil law. Nullity. Acquisition of a third party`s good.

Para citar este artigo (ABNT NBR 6023:2018)

JARDIM, Mónica Vanderleia Alves de Souza. A venda de coisa alheia como própria, em Portugal. Revista Thesis Juris - RTJ, São Paulo, v. 9, n. 2, p. 397-414, jul./dez. 2020. http://doi.org/10.5585/rtj.v9i2.18759. 
Introdução

Nota prévia sobre a venda de coisa alheia como própria - O actual Código Civil, no art. 892..$^{\circ}$ COMINA A NULIDADE DO contrato de compra e venda de coisa alheia como própria ${ }^{1}{ }^{2}$, «sempre que o vendedor careça de legitimidade para a realizar» ${ }^{3}$, sendo aplicável a mesma regra aos outros contratos onerosos pelos quais se alienam bens ou se estabeleçam encargos sobre eles, de acordo com o preceituado no art. $939 .^{\circ}$ do mesmo diploma legal ${ }^{4}$.

Ao invés, desde o Código de Veiga Beirão, é permitida a venda comercial de coisa alheia como própria (cfr. art. $467 .^{\circ}$, n. $^{\circ} 2$, do Código Comercial) ${ }^{5}$. Perante esta realidade, torna-se evidente que a natureza real da compra e venda não determina, por si só, a nulidade do contrato de compra e venda de coisa alheia como própria, sempre que o vendedor careça de legitimidade para a realizar 6 . Mais, o direito italiano é um exemplo claro de que a nulidade da venda de coisa alheia não é uma consequência necessária da natureza real do contrato de compra e venda, uma

\footnotetext{
${ }^{1}$ Sobre a venda de coisa alheia como própria, vide, por todos: LIMA, PIRES DE / VARELA ANTUNES, Código Civil Anotado, vol. II, 5. ${ }^{\text {a }}$ ed., Coimbra, Coimbra Editora, 1997, p. 189 e ss.; VENTURA, RAÚL, O contrato de compra e venda no Código Civil. Venda de bens alheios - Venda com expedição, Revista da Ordem dos Advogados, 1980, p. 305 e ss.; CUNHA, PAULO OLAVO, Venda de bens alheios, Revista da Ordem dos Advogados, 1987, II, p. 523 e ss.; YARA MIRANDA, Venda de coisa alheia, Themis, Ano VI, n. ${ }^{11}$, 2005, p. 111 e Ss.).

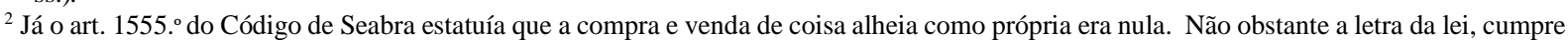
referir que parte da doutrina defendia que o contrato era válido, mas resolúvel por falta de cumprimento da obrigação do vendedor. Tal tese baseava-se em dois argumentos: não faltar ao contrato nenhum elemento essencial e o $\S$ único do art. 1455 prever a revalidação do contrato pela aquisição da coisa, sendo certo que só se revalida um contrato se este já tiver sido válido (Vide GONÇALVES, LUIZ DA CUNHA, Tratado do Direito Civil em Comentário ao Código Civil Português, vol. III, Coimbra, Coimbra Editora, 1934, p. 469). Contra esta posição afirmou-se que, efectivamente, faltava um elemento essencial — o direito que se pretendia transferir — e que a revalidação não era em absoluto incompatível com a nulidade. (Neste sentido vide VENTURA, RAÚL, loc. cit., p. 312). TELLES, GALVÃO, Contratos civis Projecto completo de um título do futuro Código Civil português e respectiva exposição de motivos, Separata da Revista da Faculdade de Direito da Universidade de Lisboa, vols. IX-X, 1953-1954, p. 158 e 159, defendia a nulidade da compra e venda, tendo em conta a gravidade da infracção e a importância dos interesses em jogo; acresce que considerava que o regime da nulidade da compra e venda de coisa alheia apenas se encontrava limitado, em face do geral, pelo facto de existir a proibição de invocação por parte do vendedor, no caso de boa fé do comprador, e por parte do comprador de má fé, em caso de boa fé do vendedor. CABRAL, AMARAL, Venda de Coisa Alheia, Coimbra, 1956, p. 113 e ss., por seu turno, referia-se à nulidade da venda de bens alheios como uma nulidade específica. Por sua vez, a jurisprudência entendia que o artigo prescrevia uma nulidade relativa (anulabilidade), por um lado, porque o contrato era válido até que a sua validade fosse contestada e, por outro, porque a venda se tornava definitivamente válida, caso o vendedor adquirisse a titularidade do direito alienado em data anterior à da evicção ou da acusação do crime em que tivesse incorrido, pois todos os requisitos da validade do negócio passariam a estar preenchidos e, consequentemente, deixaria de fazer sentido a destruição dos efeitos do negócio. (Vide, entre outros, o acórdão do Supremo Tribunal de Justiça de 12 de Junho de 1951, Boletim do Ministério da Justiça, n. ${ }^{\circ}$ 25, p. 371, e o acórdão da Relação de Coimbra de 16 de Março de 1969, Jurisprudência das Relações, 1969, 15, p. 511).

${ }^{3}$ Como se sabe, o poder de disposição de uma coisa pode caber a pessoa diversa do proprietário e, obviamente, pelo facto de existir aquele poder, a coisa não deixa de ser alheia. Por isso, a venda de coisa alheia é o contrato pelo qual uma das partes aliena como próprio, sem que para tal tenha legitimidade, um direito de outrem - que não tem a legítima expectativa de vir a adquirir -, mediante o pagamento de um preço.

${ }^{4}$ No direito português, como é consabido, se as partes considerarem o objecto da venda como alheio, o contrato segue o regime da venda de bens futuros (cfr. art. 880. ${ }^{\circ}$ e art. 893..$^{\circ}$ ambos do Código Civil).

${ }^{5}$ A venda comercial de coisa alheia gera a obrigação de aquisição da propriedade dessa coisa por parte do vendedor (cfr. $n .^{\circ} 2$ do art. $467 .^{\circ}$ do Código Comercial). A lei não faz depender a obrigação do vendedor da boa ou má fé da contraparte, o que significa que tal obrigação existe mesmo quando o comprador conhece a alienidade do direito; caso o vendedor não cumpra a obrigação que sobre si impende, incorre em responsabilidade contratual (vide art. $467 .^{\circ}$, n. $^{\circ} 2$, $\S$ único, do Código Comercial.). Adquirida a propriedade pelo vendedor, esta transmitese, imediatamente, para o comprador, passando a recair sobre aquele a obrigação de entrega e sobre este a obrigação de pagar o preço. A transferência da propriedade, tal como acontece em regra, não depende da entrega ao comprador; decorre, apenas, do contrato de compra e venda, o qual tem um efeito translativo diferido. Efectivamente, a propriedade transmite-se para o comprador, independentemente de nova manifestação de vontade.

${ }^{6}$ Acrescente-se que, como é evidente, a validade da venda de coisa alheia não pode implicar, só por si, a lesão dos direitos do verus dominus, perante quem a venda será absolutamente ineficaz. Portanto, nunca são os interesses deste que são ponderados pelo legislador - que atribui efeitos reais ao contrato de compra e venda - aquando da opção entre a validade ou a nulidade, do contrato de compra e venda de coisa alheia. De facto, a venda de coisa alheia, mesmo que seja considerada válida, é res inter alios acta, é ineficaz em relação ao proprietário e, consequentemente, não altera em nada o seu direito. O titular do direito pode perfeitamente dispor dele, mesmo após a celebração do contrato de compra e venda de coisa alheia; inclusive pode vendê-lo às partes do contrato inválido.
} 
vez que, em Itália, não obstante este contrato ser um negócio real quoad effectum (cfr. art. 1478 do Código Civil) ${ }^{7}$, a venda de coisa alheia é válida.

E, de facto, assim é - a natureza real do negócio não determina, por si só, a nulidade do contrato de compra e venda de coisa alheia como própria -, desde que se entenda, como nós ${ }^{8}$, que a natureza real do negócio em apreço não implica a imediata transmissão da propriedade (ou de outro direito), no momento do contrato, mas, supõe "apenas" que o efeito real - que pode ser diferido no tempo - seja uma mera consequência do contrato, não dependendo, portanto, da verificação de um posterior acto translativo ${ }^{9}$. Nesta lógica, o legislador do actual Código Civil pôde escolher, apesar da natureza real do negócio (cfr. arts. $874 .^{\circ}$ e $879 .^{\circ}$ do Código Civil), entre aceitar a validade ou impor a nulidade do contrato de compra e venda de bens alheios como próprios.

No entanto, a verdade é que, em matéria de compra e venda - não comercial - de coisa alheia como própria, o legislador português, segundo o nosso entendimento e na esteira da doutrina maioritária, criou um regime atípico de nulidade: ao estatuir - de acordo com o que já era defendido pela jurisprudência e por parte da doutrina na vigência do Código de Seabra que "o vendedor não pode opor a nulidade ao comprador de boa fé, como não pode opô-la ao vendedor de boa fé o comprador doloso" (cfr. art. $892 .^{\circ}$ do Código Civil) ${ }^{10}$; ao continuar a prever a possibilidade de o negócio se "convalidar", ou ver sanado o vício, transferindo-se o direito logo que o vendedor o adquira por algum modo (cfr. art. 895. ${ }^{\circ}$ do Código Civil); ao

\footnotetext{
${ }^{7}$ Nos termos do art. 1470 do Código Civil italiano, a compra e venda é um contrato que tem por objecto a transmissão da propriedade de uma coisa ou de um direito, mediante o pagamento de um preço. Portanto, a transferência da propriedade é um dos efeitos essenciais do contrato sendo, consequentemente, inquestionável o facto de o ordenamento jurídico italiano ter adoptado a concepção real de compra e venda. No entanto, o legislador, ao elencar as obrigações principais do vendedor - além de ter voltado a salientar o efeito translativo da convenção -, admitiu a possibilidade de a venda não causar imediatamente a transferência da propriedade, prevendo que nesse caso o vendedor fica obrigado a fazer com que a contraparte adquira o direito, quer esta esteja de boa ou de má fé. Por isso, a venda de coisa alheia (cfr. art. 1478, n. 2 do Codice Civile) é apresentada como um exemplo de um contrato translativo obrigacional ou obrigatório. Sublinhe-se, por fim, que o comprador pode exigir a resolução do contrato sempre que o haja concluído ignorando a alienidade do bem, desde que, entretanto, o vendedor não tenha cumprido a obrigação de o fazer adquirir a propriedade (cfr. art. 1479 do Código Civil italiano). Resolvido o contrato, o vendedor deve restituir ao comprador o preço pago, mesmo que a coisa tenha diminuído de valor ou esteja deteriorada, acompanhado das despesas e pagamentos feitos para a realização do contrato. Mas, se a coisa tiver diminuído de valor ou se se houver deteriorado em virtude de facto praticado pelo comprador, e se este tiver auferido algum benefício, então o valor desse proveito será deduzido ao montante que a contraparte está obrigada a restituir-lhe. Acresce que o adquirente tem direito ao reembolso das despesas necessárias e úteis realizadas na coisa e, em caso de má fé do vendedor, também das voluptuárias (cfr. art. 1479 do Código Civil italiano).

${ }^{8}$ JARDIM, MÓNICA, ob. cit., p. 451, e A ACTUAL problemática a propósito do princípio da consensualidade, Boletim da Faculdade de Direito, VOL. XC, T. I, Coimbra, 2014, p. 182, 183, 195, 212 e ss.

${ }^{9} \mathrm{Ou}$ seja, nos ordenamentos jurídicos que reconheçam à compra e venda efeitos meramente obrigacionais, a venda de coisa alheia tem de ser havida como válida. A referida validade é uma decorrência da eficácia meramente obrigacional: se os efeitos são meramente obrigacionais, obviamente, a venda de coisa alheia não pode ser havida como nula. Ao invés, nos ordenamentos jurídicos, como o português e o italiano, que atribuem à compra e venda eficácia real, desde que se entenda que tal eficácia real não tem de ser imediata, tem de se afirmar que o legislador pode optar entre proibir a venda de coisa alheia, impondo como sanção a nulidade, ou considerá-la válida. Não obstante, caso a opção seja esta última, a verdade é que a venda só produzirá o efeito real se e quando a coisa se tornar própria do alienante. Assim, como é evidente, se tal aquisição nunca chegar a ocorrer, a venda, apesar de válida, nunca realizará a sua função típica, uma vez que nunca produzirá qualquer efeito real. Refira-se, por fim, que caso o legislador opte pela nulidade, pode criar um regime atípico, impondo ao vendedor a obrigação de adquirir o direito e prevendo a possibilidade do negócio se "convalidar" ou ver sanado o vício, logo que a referida aquisição ocorra.

10 “A boa fé, nestes casos, consiste na ignorância de que a coisa vendida não pertencia ao vendedor" (Cfr. LIMA, PIRES DE / VARELA, ANTUNES, ob. cit., p. 190). Saliente-se ainda que o dolo da secção da venda de coisa alheia não é empregue com o mesmo significado do dolo-culpa do art. $483 .^{\circ},{ }^{\circ}{ }^{\circ}$, mas sim no sentido da má fé, aproximando-se do dolo do art. 253. ${ }^{\circ}$. (Neste sentido, vide por todos: LIMA, PIRES DE / VARELA, ANTUNES, Código Civil Anotado, vol. II, ob. cit., p. 190; CORDEIRO, MENEZES, Da Boa Fé no Direito Civil, Coimbra, Almedina, 1997, p. 497 e ss.; CUNHA, PAULO OLAVO, Venda de Bens Alheios, loc. cit., p. 452).
} 
impor ao vendedor, de forma inovadora, a obrigação de sanar a nulidade da venda, ou convalidar o negócio, adquirindo o direito vendido, quando o comprador esteja de boa fé (cfr. art. $897 .^{\circ}$, n. $^{\circ} 1$, do Código Civil $)^{11}{ }^{12}{ }_{-}^{13}$; bem como, a obrigação de indemnizar o comprador, nos termos dos arts. $898 .^{\circ}$ a $900 .^{\circ}$ do Código Civil, e de restituir integralmente o preço (art. 894. ${ }^{\circ}$, n. ${ }^{\circ}$ 1, do Código Civil), mesmo que o comprador não possa restituir a coisa ${ }^{14}$.

Assumimos, portanto, a posição da grande maioria da doutrina nacional que: não concebe a compra e venda de bem alheio como próprio enquanto um contrato translativo obrigatório ou obrigacional; não reconhece uma qualquer obrigação de transmitir o direito a cargo do alienante; defende que o direito é adquirido pelo comprador, quando o é, por efeito do contrato convalidado.

Portanto, a propriedade transfere-se para o comprador por simples efeito da convalidação do contrato que ocorre em momento cronologicamente simultâneo, mas logicamente anterior, à transferência; nenhum outro acto é necessário ${ }^{15}$.

\section{Tese de validade da venda de bens alheios}

Análise crítica tese segundo a qual a venda de bens alheios é válida, embora resolúvel, porque produz, desde logo, o efeito de obrigar o vendedor a adquirir o direito ou a diligenciar

${ }^{11} \mathrm{O}$ comprador de boa fé pode obter do tribunal a fixação de um prazo para a convalidação, nos termos dos artigos $1456 .^{\circ}$ e $1457 .^{\circ}$ do Cód.Proc.Civil, subordinando ao decurso do prazo a propositura da acção tendente à declaração de nulidade.

${ }^{12}$ A letra da lei é clara. A obrigação só estará cumprida, ou seja, o vício só estará sanado, se e quando o vendedor adquirir a propriedade do bem alienado. Não releva se o vendedor efectuou todos os esforços necessários para que o comprador adquirisse a propriedade, a lei exige a convalidação concreta do contrato. (Neste sentido se pronuncia a doutrina em geral, uma vez que, se assim não fosse, a obrigação de convalidação não teria efeitos práticos. Por todos, vide: VENTURA, RAÚL, loc. cit., p. 317; CUNHA, PAULO OLAVO, loc. cit., p. 458).

${ }^{13}$ Apesar de em causa estar uma nulidade atípica, entendemos que é o regime da nulidade o aplicável, sempre que não seja contrariado por alguma das especificidades referidas. Assim, por exemplo, o único limite de tempo para a invocação da nulidade é, obviamente, a convalidação do contrato e, na nossa perspectiva, a convalidação do contrato só ocorre se o vendedor adquirir o direito do verus dominus ou se este suceder inter vivos na posição do devedor. (Neste sentido vide LIMA, PIRES DE / VARELA, ANTUNES, ob. cit., p. 193). Sublinhese, por fim, que do Código Civil nada resulta quanto ao poder ou faculdade de o tribunal declarar oficiosamente a nulidade da venda, o que justifica a diversidade de posições adoptadas pela doutrina. Segundo alguns Autores, na ausência de disposição legal, aplica-se o regime geral da nulidade, podendo e devendo, consequentemente, o tribunal declarar oficiosamente a nulidade. Nesta perspectiva, o legislador apenas impôs restrições à legitimidade das partes, não mais. (Vide LIMA, PIRES DE / VARELA, ANTUNES, ob. cit., p.190). Em sentido contrário manifesta-se: SOTTOMAYOR, CLARA, Invalidade e Registo - A Protecção do Terceiro Adquirente de Boa Fé, Coimbra, Almedina, 2010, p. 857; MIRANDA, YARA, loc. cit., p. 132 e ss., uma vez que considera que a venda de coisa alheia como própria não é nula, mas sim resolúvel. VENTURA, RAÚL, loc. cit., p. 316, por seu turno, por um lado, considera que o alcance do art. 892. ${ }^{\circ}$ perderia efeito útil com a declaração oficiosa da nulidade - uma vez que a parte, que não podia arguir a nulidade, conseguiria obter, por outra via, o resultado que a lei lhe negava, bastando para tanto intentar uma acção exigindo o cumprimento da prestação da contraparte, pois, nesse caso, o tribunal declararia oficiosamente a nulidade e o autor libertar-se-ia das obrigações impostas por lei. Mas, por outro, afirma que não impor ao tribunal o dever de reconhecer a nulidade levá-lo-ia a condenar as partes a cumprir um contrato inválido - por exemplo, se o comprador de boa fé exigisse ao vendedor a entrega da coisa, o vendedor não lhe poderia opor a nulidade do contrato e o tribunal, impedido de conhecer a nulidade, teria de condená-lo a entregar a coisa e, assim, a praticar um acto que, para além de não corresponder ao cumprimento de qualquer obrigação - uma vez que em causa estava um contrato nulo -, seria legalmente impossível, pelo facto de a coisa pertencer a outrem. Por isso, este Autor defende que "o tribunal deve declarar oficiosamente a nulidade, para os efeitos que a lei atribui a tal nulidade, não condenando à entrega da coisa ou do preço, mas sim naquilo em que deva condenar, conforme os mencionados efeitos" (No mesmo sentido CUNHA, PAULO OLAVO, loc. cit., p. 452 e 453 ).

${ }^{14}$ Não obstante tenha de ser deduzido o proveito obtido pelo comprador em virtude da própria perda ou diminuição do valor da coisa vendida, por exemplo, através de um prémio de seguro ou de uma indemnização paga por um terceiro (art. $894 .^{\circ}$, n..$^{\circ}$ 2), como forma de se evitar o enriquecimento à custa alheia.Neste sentido, vide acórdão do Supremo Tribunal de Justiça de 29 de Junho de 2006 , http://www.dgsi.pt/jstj.nsf., [consultado em 16 de Novembro de 2009].

${ }^{15}$ Neste sentido, vide VENTURA, RAÚL, loc. cit., p. 315. Não concordamos, portanto, com MIRANDA, YARA, loc. cit., p. 135, nota 66, que considera que, na prática, o vendedor pode nunca chegar a ser proprietário do bem vendido, transferindo-se a propriedade automaticamente do verdadeiro proprietário para o comprador. 
no sentido da aquisição por parte do comprador, ficando, no entanto, os efeitos normais do contrato de compra e venda suspensos até ao cumprimento dessa obrigação ${ }^{16}$ - Segundo YARA MIRANDA ${ }^{17}$, não obstante o Código Civil declarar nula a venda de coisa alheia, ela é válida, uma vez que produz, pelo menos, um efeito: a obrigação de o vendedor adquirir o direito ou de diligenciar no sentido da aquisição da propriedade por parte do comprador. Por isso, afirma que, caso o vendedor não cumpra a obrigação a que está adstrito, o contrato não é nulo, é resolúvel por incumprimento.

Para melhor se compreender o raciocínio da Autora, passamos a transcrever partes do seu texto:

\begin{abstract}
Quer na venda civil como na comercial, o vendedor está obrigado a conseguir que o comprador adquira a propriedade do bem alienado. A diferença é que o CC exige a boa fé do comprador como pressuposto da existência da referida obrigação." [...] "Se a venda produz este efeito essencial, como poderá ser nula? A nulidade não coaduna com a produção de qualquer efeito típico do contrato." [...] "É uma venda válida, ainda que os efeitos normais do contrato de compra e venda fiquem suspensos até a realização da prestação do vendedor. Uma vez cumprida tal obrigação [a de adquirir a propriedade ou de diligenciar no sentido da aquisição da propriedade por parte do comprador], todos os outros efeitos efectivam-se: a propriedade transfere-se para o comprador [caso não tenha sido adquirida directamente do verus dominus], este fica obrigado a pagar o devido preço e o vendedor a entregar a coisa." ${ }^{18}[\ldots]$ "A venda, quer civil quer comercial, de coisa alheia é válida perante o ordenamento jurídico português. Apesar de o direito civil e do direito comercial encararem a venda de direito de outrem de prismas diferentes, os resultados a que chegam são no essencial idênticos". [...] "A venda é parcialmente ineficaz, porém, ineficácia e invalidade são dois vícios absolutamente distintos." [...] "Onde a lei fala de nulidade e de convalidação, deve-se ler resolubilidade e execução, respectivamente. De acordo com o regime consagrado pelo $\mathrm{CC}$, a venda de coisa alheia é absolutamente válida e resolúvel pelo incumprimento da obrigação que impende sobre o vendedor de diligenciar no sentido da aquisição da propriedade por parte do comprador.
\end{abstract}

Como já resulta do afirmado, não podemos concordar com a tese apresentada. Passamos a explicitar o nosso entendimento.

A) - Se o legislador pretendesse que a compra e venda de coisa alheia fosse válida, embora produzisse, imediatamente, apenas, o efeito de fazer surgir na esfera jurídica do vendedor a obrigação de adquirir o direito ou de diligenciar no sentido da aquisição da propriedade por parte do comprador, ficando diferidos os restantes efeitos até ao cumprimento dessa obrigação, não teria fixado a sanção da nulidade. Na verdade, a proibição da venda - não comercial - de bens alheios como próprios, resultou de uma clara opção do legislador nacional. Tal parece-nos evidente quando se tem em conta, por um lado, que o art. $1555 .^{\circ}$ do Código de Seabra -

\footnotetext{
${ }^{16}$ Vide, ainda, ALMEIDA, CARLOS FERREIRA DE, Transmissão contratual da propriedade - Entre o mito da consensualidade e a realidade de múltiplos regimes, Themis, Ano VI, n. ${ }^{\circ}$ 11, 2005, p. 15.

${ }^{17}$ MIRANDA, YARA, loc. cit., p. 142 e ss.

${ }^{18}$ As frases introduzidas entre parêntesis rectos são nossas, uma vez que só assim entendemos na íntegra o raciocínio da Autora.
} 
distanciando-se da solução consagrada no Direito Comercial (desde o Código de Veiga Beirão) - já prescrevia a nulidade da compra e venda de coisa alheia, não sendo, aliás, a interpretação doutrinal deste artigo unânime. E, por outro lado, a diversa solução adoptada pelo Código Civil italiano, tão bem conhecida pelo legislador nacional.

Esta opção fundou-se, além do mais, nos seguintes argumentos: a regra da proibição de venda de coisa alheia é mais conforme com a essência do direito civil; assegura uma maior nitidez da situação, sobretudo aos olhos dos leigos; não estimula "desonestos ou aventureiros a tentativas de intromissão ilícita na esfera alheia" ${ }^{19}$; não se justifica a consagração da validade da venda de coisa alheia, uma vez que não se sentem as necessidades justificativas do preceito de direito comercial.

Assim, em face da norma que prescreve a nulidade da compra e venda civil de bens alheios, defender a sua validade é, no mínimo, fazer uma interpretação não conforme ao preceituado no n. ${ }^{\text {os }} 2$ e 3 do art. 9..$^{\circ}$ do Código Civil.

B) - A obrigação que impende sobre o vendedor - quando o comprador esteja de boa fé - de adquirir o direito vendido para, assim, sanar a nulidade da venda, ou convalidar o negócio (cfr. art. 897. ${ }^{\circ}$, n. ${ }^{\circ} 1$, do Código Civil), não é um efeito essencial do contrato de compra e venda civil; o efeito essencial da compra e venda é a transferência do direito, não a obrigação de adquirir, para depois transmitir o direito.

Mais, a referida obrigação não emerge (não pode emergir) - ao contrário do que ocorre na venda comercial de coisa alheia que é válida - do contrato nulo, resulta, isso sim, do regime da nulidade que é uma consequência do vício do contrato, ou por outra via, que tem por fonte própria e directa apenas a lei ${ }^{20}$.

C) - O legislador sentiu necessidade de elaborar dois preceitos legais a propósito do dever de indemnizar o comprador de boa fé pelos danos derivados do contrato nulo (cfr. arts. 898. ${ }^{\circ}$ e 899..$^{\circ}$ do Código Civil) e, ainda, de impor a obrigação de o vendedor indemnizar o comprador quando a venda não seja convalidada (cfr. art. 900. ${ }^{\circ}$ do Código Civil). Ora, se a obrigação de convalidar o contrato, adquirindo o direito vendido, emergisse do próprio contrato, como é evidente, caso não ocorresse a convalidação, o comprador só poderia ser indemnizado pelo prejuízo que não teria sofrido caso a compra e venda não tivesse sido celebrada - ao abrigo dos

${ }^{19}$ VENTURA, RAÚL, loc. cit., p. 306.

${ }^{20}$ No mesmo sentido, por todos, vide TELLES, GALVÃO, loc. cit., p. 158. 
arts. $898 .^{\circ}$ e $899 .^{\circ}$ do Código Civil. Ou seja, só se justifica a existência do art. 900. ${ }^{\circ}$ do Código Civil, porque o incumprimento da obrigação de sanar a nulidade da venda - imposta pelo art. 897. ${ }^{\circ}$ do Código Civil - não se traduz num incumprimento do contrato, mas sim de uma obrigação imposta por $1 \mathrm{ei}^{21}$, em virtude da nulidade do contrato. Por isso, surgem as duas obrigações de indemnizar perfeitamente distintas: uma delas pelo interesse contratual negativo, pois resulta do facto de ter sido celebrado um contrato nulo por a coisa vendida não pertencer ao vendedor; a outra, pelo interesse contratual positivo, sempre que não ocorra a convalidação e, assim, não seja cumprida a obrigação imposta por lei.

D) - A obrigação de convalidar o contrato nulo ou de adquirir a coisa ou o direito vendido, embora conduza à aquisição por parte do comprador, não se traduz no cumprimento de uma obrigação de fazer com que o comprador adquira o direito. De facto, nem o art. $879 .^{\circ}$ do Código Civil, nem o $§$ único do n. ${ }^{\circ} 2$ do art. 467 do Código Comercial, se referem à obrigação de o vendedor fazer o comprador adquirir o direito o que, naturalmente, significa que tal obrigação não se traduz num dos efeitos da compra e venda, mesmo da comercial.

O legislador português, quer no art. $897 .^{\circ}$ do Código Civil, quer no $\S$ único do $n .^{\circ} 2$ do art. $467 .^{\circ}$ do Código Comercial, apenas impõe ao vendedor a obrigação de adquirir o direito vendido, já não a de o transmitir, porque, logo que o vendedor adquira, por algum modo, a propriedade da coisa ou o direito vendido, ocorre a sanação do vício, tornando-se, assim, válido o negócio jurídico e, em consequência, o direito transfere-se, automaticamente, para o comprador, por mero efeito do contrato convalidado, não sendo necessário um qualquer outro acto (cfr. art. $895 .^{\circ}$ do Código Civil).

Em resumo, nem sequer existe a obrigação de fazer o comprador adquirir o direito

Consequentemente, o vendedor ao cumprir a obrigação de adquirir a coisa ou o direito, está "apenas" a actuar por forma a que a venda real produza o seu efeito essencial: a transmissão do direito real.

Porque assim é, consideramos que, também na hipótese de venda de coisa alheia (quer civil, quer comercial) não tem cabimento falar entre nós, ao contrário do que ocorre em Itália, de um contrato translativo obrigacional ou obrigatório. Ou seja, em causa não está, nem pode estar, de acordo com a lei, um contrato de compra e venda que crie uma fase intermédia entre a sua celebração e o momento em que a transmissão do direito se opera, fase essa de natureza obrigacional compatível com a atribuição do efeito translativo ao próprio contrato. O mesmo é

${ }^{21}$ Neste sentido, vide: TELLES, GALVÃO, loc. cit., p. 127.; MARTINEZ, ROMANO, Direito das Obrigações (Parte Especial). Contratos.

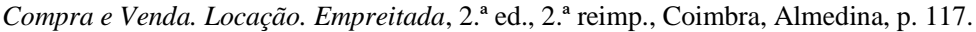


dizer: um contrato de compra e venda que faça surgir na esfera jurídica do vendedor a obrigação de fazer com que o comprador adquira o direito ou a coisa.

E) - Mesmo abstraindo, por um lado, da circunstância de a nulidade supor um vício originário do negócio jurídico, enquanto a resolução não envolve qualquer vício formativo ou estrutural do negócio - mas sim a ocorrência de factos posteriores à conclusão do contrato, frustrantes do interesse na execução contratual ou desequilibradores da relação de equivalência económica entre as prestações - e, por outro, do facto de o vício do contrato não ficar sanado e de o comprador não adquirir o direito, apesar de o vendedor o adquirir, se em data anterior à da aquisição já tiver ocorrido um dos factos previstos no n. ${ }^{\circ} 1$ do art. $896 .^{\circ}$ do Código Civil ${ }^{22}$, entendemos que não é possível esquecer que o regime da resolução por incumprimento difere, e muito, do regime da nulidade, mesmo do regime da nulidade atípica que - no nosso entendimento e na esteira da doutrina dominante - o legislador consagrou em matéria de venda de coisa alheia. Consequentemente, não podemos aceitar a tese segundo a qual onde na lei se lê nulidade e convalidação, deve ler-se resolubilidade e execução, respectivamente.

De facto, ainda que se entenda, como nós, que o verus dominus não tem legitimidade para intentar a acção de nulidade ${ }^{23}$, uma vez que o negócio é perante si absolutamente ineficaz podendo defender o seu direito através de uma acção de defesa do direito real (acção negatória ou acção de reivindicação, consoante as circunstâncias em concreto, na qual pode cumular um pedido de indemnização) -, e que se considere que o tribunal não pode conhecer e declarar oficiosamente a nulidade atípica - posição que não compartilhamos porque somos sensíveis aos argumentos e aderimos à tese de RAÚL VENTURA nos termos da qual o tribunal deve declarar oficiosamente a nulidade atípica para os efeitos que a lei lhe atribui, não condenando à entrega da coisa ou do preço, mas sim naquilo em que deva condenar, conforme os efeitos previstos na lei -, não se pode esquecer que:

\footnotetext{
${ }^{22}$ Salvaguardadas, claro está, as hipóteses previstas na lei em que a aquisição não pode já conduzir à convalidação (cfr. art. $896 .^{\circ}$ do Código Civil). A saber:

- Pedido judicial de declaração da nulidade do contrato, formulado por um dos contraentes contra o outro;

- Restituição do preço ou pagamento da indemnização, no todo ou em parte, com aceitação do credor;

- Transacção entre os contraentes, na qual se reconheça a nulidade do contrato;

- Declaração escrita, feita por um dos estipulantes ao outro, de que não quer que o contrato deixe de ser declarado nulo.

Hipóteses estas que se traduzem num impedimento à convalidação porque, de forma expressa ou implícita, uma das partes (ou ambas) já, previamente, manifestou a vontade de radicar ou consolidar a nulidade do contrato. (Vide RAÚL VENTURA, O contrato de compra e venda no Código Civil. Venda de bens alheios - Venda com expedição, loc. cit., p. 315).

Refira-se, por fim, que o n. ${ }^{\circ} 2$ do artigo em apreço, tendo em conta o estatuído no art. $892^{\circ}$, prescreve que os dois primeiros casos apresentados não assumem relevância se forem praticados pela parte que não pode invocar a nulidade.

${ }^{23}$ No mesmo sentido vide Supremo Tribunal de Justiça de 12 de Junho de 1951, Boletim do Ministério da Justiça, n. ${ }^{\circ} 25$, p. 371-373 e o acórdão da Relação de Coimbra de 28 de Abril de 1987, Colectânea de Jurisprudência, 1987, Ano XII, Tomo II, p. 97. Em sentido contrário, vide o acórdão da Relação do Porto de 8 de Março de 1957, Jurisprudência da Relação, III, p. 383 e acórdão do Supremo Tribunal de Justiça de 13 de Dezembro de 1984, Boletim do Ministério da Justiça, 1985,n. ${ }^{\circ} 342$, p. 361 e ss.
} 
- Qualquer interessado, com interesse legítimo, pode invocar a nulidade atípica, mas não resolver o contrato;

- A nulidade, como resulta da lei, é invocável a todo o tempo, enquanto não ocorrer a convalidação do contrato (cfr. art. $895 .^{\circ}$ do Código Civil); já o direito de resolução, de acordo com o art. 436, n. ${ }^{\circ} 2$ do Código Civil, extingue-se ou caduca quando não for exercido no prazo convencionado ou no prazo razoável fixado pela contraparte ao titular do direito e, não se verificando qualquer destas situações, e na ausência de prazo legal de caducidade do direito, já se defendeu que o direito de resolução fica sujeito à prescrição ordinária ${ }^{24}$.

- A declaração de nulidade tem efeito retroactivo real, sendo consequentemente, afectados os "terceiros" subadquirentes, salvaguardados aqueles que preencham os requisitos do art. 291. ${ }^{\circ}$ do Código Civil se já tiverem decorrido três anos sobre a data do negócio nulo e não tiver sido proposta e registada acção.

Ao invés, entre nós, tal como em Itália, o direito substantivo não reconhece, em geral, eficácia retroactiva real à resolução ${ }^{25}$, não sendo, portanto, em regra, os terceiros afectados pela cessação da eficácia do negócio jurídico, quer tenham adquirido de boa, ou má fé, a título gratuito, ou oneroso (cfr. art. $435 .^{\circ}$, n. $^{\circ} 1$ do mesmo diploma legal). Efectivamente, apenas excepcionalmente, quando em causa estejam bens sujeitos a registo, a inscrição da acção conduz à extinção dos direitos adquiridos pelos "terceiros", quer na pendência da acção quer ante litem, se estes não tiverem obtido a inscrição do seu facto aquisitivo com prioridade. Portanto, como resulta do acabado de afirmar, o terceiro, ainda que haja adquirido a título gratuito e de má fé, não será afectado pela resolução, se tiver obtido a inscrição do seu facto aquisitivo antes da feitura do registo da acção. E isto, independentemente do decurso de qualquer prazo sobre a data da conclusão do contrato resolvido ${ }^{26}$, mantendo-se, assim, nesse caso, a regra da irrectroactividade real da resolução (art. $435 .^{\circ}$, n. $^{\circ}$ 2, do Código Civil).

\footnotetext{
${ }^{24}$ PROENÇA, BRANDÃO, A Resolução do Contrato no Direito Civil- Do Enquadramento e do Regime, reimp., Coimbra, Coimbra Editora, 2006, p. 155 e 156.

${ }^{25}$ A resolução tem, em princípio, efeito retroactivo entre as partes (art. $433 .^{\circ}$, n. ${ }^{\circ}$ 1: "na falta de disposição especial, a resolução é equiparada, quanto aos seus efeitos, à nulidade ou anulabilidade do negócio jurídico, com ressalva do disposto nos artigos seguintes"). No entanto, esta regra envolve desvios, nos termos do art. $434 .^{\circ}$, n. $^{\circ} 1$, segunda parte: "salvo se a retroactividade contrariar a vontade das partes ou a finalidade da resolução".

${ }^{26}$ Acresce que é absolutamente irrelevante que antes do registo do facto aquisitivo do "terceiro" o Registo já publicitasse o eventual direito potestativo de resolução no extracto da inscrição de aquisição lavrada com base no contrato resolvido. Por isso se reconhece ao registo do direito potestativo de resolução uma função de mera publicidade notícia: advertir terceiros, para que não sejam surpreendidos com o eventual registo da acção de resolução. (Vide, JARDIM, MÓNICA, A incerteza gerada pelo registo, com efeito enunciativo, de um facto apenas eficaz inter partes, in, O Contrato na Gestão do Risco e na Garantia da Equidade, Coordenação: António Pinto Monteiro, Instituto Jurídico, Faculdade de Direito da Universidade de Coimbra, p. 303 e ss.
} 


\section{Tese de nulidade parcial da venda de bens alheios}

A tese segundo a qual a venda de coisa alheia como própria é, apenas, parcialmente nula - Contra a posição maioritária da doutrina segundo a qual a compra e venda civil de coisa alheia é total ou absolutamente nula, salvaguardada a hipótese prevista no art. $902 .^{\circ}$ do Código Civil, CLARA SOTTOMAYOR defende que tal "como a doutrina tem defendido a cisão dos efeitos do negócio jurídico entre as partes e em relação a terceiros, através da teoria da inoponibilidade dos negócios não registados, [...] a melhor forma de explicar o regime da venda de bens alheios é recorrer a uma cisão dos efeitos jurídicos do negócio nulo, admitindo que há consequências jurídicas que não se produzem, em virtude da nulidade, e outras que se produzem, por não contradizerem a finalidade da norma que consagra a nulidade." 27.

Por isso, esta Autora assume o entendimento segundo o qual a venda de bens alheios é um negócio que padece de nulidade parcial quanto a algumas das suas consequências jurídicas.

Para facilitar a compreensão da tese em apreço passamos a citar a Autora:

O contrato parcialmente nulo, porque não produz o seu efeito real típico, é, no entanto, fonte de obrigações negociais, como o dever de entrega da coisa e a obrigação de pagar o preço; a obrigação de convalidação do contrato (arts $895 .^{\circ}$ e $897 .^{\circ}$ ) e o dever de indemnizar o comprador pelo não cumprimento ou pelo cumprimento tardio desta obrigação, assim como pelo facto de o contrato não ser válido desde o início (arts. $898 .^{\circ}$ a $900 .^{\circ}$ ). (...) Trata-se, em nossa opinião, de efeitos negociais, que resultam do contrato nulo, e são imputáveis à vontade das partes. Uma vez que a nulidade não pode ser declarada oficiosamente pelo tribunal e que o contrato nulo é susceptível de execução voluntária ou coerciva, por iniciativa do comprador de boa fé, desde que o verdadeiro proprietário não reivindique a coisa, temos, neste contexto, um círculo restrito, em que a venda de bens alheios é um negócio parcialmente válido, quanto a algumas das suas consequências jurídicas. (...) Relativamente à obrigação de convalidação (art. 897..$^{\circ}$ ), cremos tratar-se de um efeito negocial do contrato nulo, produzindo-se o efeito real, depois da convalidação, nos termos do art. $895 .^{\circ}$, como um efeito produzido pelo contrato convalidado, a que a lei atribui efeitos transmissivos automáticos, a favor do comprador, com eficácia retroactiva à data da celebração do contrato nulo. ${ }^{28}$

Ainda segundo CLARA SOTTOMAYOR, à inoponibilidade da nulidade ao terceiro adquirente de boa fé corresponde um direito legal relativo adquirido pelo terceiro, por força da sua boa fé. Ou seja:

o instrumento de protecção do comprador de boa fé não consiste, apenas, em meios processuais de defesa, como a recusa de legitimidade ao vendedor para invocar a nulidade e a possibilidade de o comprador de boa fé opor uma excepção, contra o vendedor $-\mathrm{a}$ inoponibilidade da nulidade. À defesa processual corresponde o reconhecimento legal de um direito relativo do comprador contra o vendedor, de acordo com o processo de substancialização das figuras meramente processual ${ }^{29}$.

\footnotetext{
${ }^{27}$ Cfr. CLARA SOTTOMAYOR, ob. cit., p. 846.

${ }^{28}$ Idem, p. 858-859.

${ }^{29}$ Idem, p. 858.
} 
Portanto, na sua opinião, a inoponibilidade da nulidade, entre as partes, não tem apenas um significado processual, mas também um significado material. Traduz-se "no reconhecimento, por força da lei, de um direito legal relativo, ao adquirente de boa fé, na medida em que, entre as partes, tudo se passa como se o negócio tivesse sido validamente celebrado." 30

Por fim, segundo esta Autora, o adquirente de boa fé é titular de um direito relativo que se apresenta como "uma figura próxima do direito de crédito, na medida em que consiste no poder de oposição, perante a invocação da nulidade do negócio, pelo alienante, e no poder de exigir, a este, a entrega da coisa, o cumprimento da obrigação de convalidação do contrato ou uma indemnização para a hipótese de incumprimento"31.

Também não subscrevemos a tese de CLARA SOTTOMAYOR, pois, repetimos, na nossa perspectiva, de acordo com as normas legais e com o resultado da sua correcta interpretação, a venda de coisa alheia é nula: totalmente nula, não apenas parcialmente nula.

\section{Conclusão}

De facto, consideramos que os argumentos avançados por CLARA SOTTOMAYOR, em defesa da tese da nulidade parcial, não procedem.

Concretizando:

A) - Não concordamos com a doutrina que afirma que antes do registo os direitos reais apenas produzem efeitos inter partes e só depois passam a ser eficazes erga omnes. De facto, segundo o nosso entendimento, entendemos os direitos reais são sempre eficazes erga omnes, não existem direitos reais apenas eficazes inter partes; o registo, entre nós, limita-se a consolidar a eficácia erga omnes, e, quando o mesmo não é lavrado, se o direito do terceiro registal prevalece, tal não constitui qualquer excepção à eficácia, preferência e sequela do direito real primeiramente constituído, mas não registado, pela simples razão de que, nesse caso, em benefício do terceiro registal, tal direito real deixa de existir ou sofre uma contracção.

Porque assim é, naturalmente, consideramos que a referida doutrina não pode dar um qualquer suporte à tese de que a venda de coisa alheia é apenas parcialmente nula.

B) - Afirmar que a venda de coisa alheia é parcialmente nula, segundo o nosso entendimento, é contra legem.

\footnotetext{
${ }^{30}$ Idem, p. 864.
}

${ }^{31}$ Idem. 
A venda civil de coisa alheia é totalmente nula, porque, como já o referimos, e escusamos de repetir, tal resultou de uma clara opção do legislador português aquando da redacção do actual Código Civil.

Nem se diga, como CLARA SOTTOMAYOR, "que a distinção entre o regime da nulidade e o regime que resultaria da validade do negócio jurídico não é muito grande, como demonstra o regime da venda comercial de coisa alheia, válida, segundo o art. 467..$^{\circ}$ do Código Comercial." Uma vez que, "no caso da venda de bens alheios, a lei parte do princípio da nulidade, mas a nulidade é atenuada pela possibilidade de convalidação e pelo regime da inoponibilidade entre as partes, produzindo o contrato nulo alguns efeitos jurídico-negociais [...]. Na venda comercial, apesar da regra da validade, o vendedor assume também a obrigação de adquirir a propriedade da coisa vendida. Na falta de cumprimento desta obrigação, o negócio não produz efeitos: estamos perante uma violação do contrato e o vendedor tem o dever de indemnização dos prejuízos causados ao comprador, sendo o seu montante calculado de acordo com os mesmos critérios." ${ }^{32}$. Efectivamente, tal argumento não procede, desde logo, por um lado, porque esquece a circunstância de o vendedor só estar obrigado a adquirir a coisa vendida, nos termos do art. $897 .^{\circ}$, n. ${ }^{\circ}$, do Código Civil, para assim convalidar a venda, quando o comprador esteja de boa fé, o que, como se sabe, não ocorre na compra e venda comercial de coisa alheia. E, por outro, porque não dá qualquer relevância ao facto de o legislador reconhecer legitimidade para arguir a nulidade: ao vendedor de boa fé em face do comprador de má fé; ao comprador - que não tenha actuado com dolo -, perante o vendedor - independentemente da boa ou má fé deste ${ }^{33}$; a qualquer eventual terceiro, com interesse legítimo.

Segundo o nosso entendimento, podendo a nulidade ser arguida por uma das partes ${ }^{34}$, ou por um terceiro com legítimo interesse, não se pode afirmar que a ininvocabilidade da nulidade pelo alienante perante o comprador de boa fé implique a validade, mesmo que parcial, da venda.

Nem se argumente que também na venda civil de coisa relativamente futura o negócio apenas produz $a b$ initio efeitos obrigacionais, só produzindo efeitos reais quando a coisa é adquirida pelo alienante e nunca os produzindo se a referida aquisição não chegar a ocorrer, uma vez que, nessa hipótese, o legislador admitiu a validade da venda, precisamente, por em causa estar uma coisa futura. Ou seja, a venda de coisa relativamente futura só é válida porque

\footnotetext{
${ }^{32}$ Cfr. CLARA SOTTOMAYOR, ob. cit., p. 862.

${ }^{33}$ Saliente-se que "quanto ao comprador, para que ele perca o direito de opor a nulidade ao vendedor [...], não basta que conheça a verdadeira titularidade da coisa. É necessário ainda que ele tenha induzido o alienante em erro ou que, apercebendo-se do erro, o tenha dissimulado, para manter o vendedor na sua falsa convicção. (Cfr. LIMA, PIRES DE / VARELA, ANTUNES, ob. cit., p. 185).

${ }^{34}$ Por isso, quando em causa está uma venda civil de coisa alheia, não se pode afirmar, como o faz a Autora, que inter partes "tudo se passa como se o negócio tivesse sido validamente celebrado".
} 
a coisa já existe e, apesar de ainda não estar em poder do disponente no momento da declaração negocial, este já ter uma legítima expectativa de vir a adquiri-la e o contrato ser realizado na perspectiva ou suposição (de ambas as partes) de que ela virá a entrar no património do alienante. Ao invés, o legislador determinou a nulidade da venda civil de coisa alheia, porque o disponente não tem a legítima expectativa de vir a adquiri-la e o contrato não é realizado na perspectiva ou suposição (de ambas as partes) de que ela virá a entrar no património do alienante (cfr. art. 893. ' do Código Civil, nos termos do qual, "a venda de bens alheios fica, porém, sujeita ao regime da venda de bens futuros, se as partes os considerarem nesta qualidade").

Sublinhe-se, ainda, que admitir que a venda de coisa alheia é apenas parcialmente nula, porque atinge apenas os seus efeitos reais, implica admitir como que uma "redução do negócio jurídico"35. Não podemos aceitar tal solução, uma vez que, como se sabe, quando um contrato padece de nulidade parcial pode ser objecto de redução, "salvo quando se mostre que este não teria sido concluído sem a parte viciada". Acresce que a redução só pode ocorrer se a parte sã do negócio assegurar a realização da intenção prática que determinou as partes à sua celebração. Ou, por outras palavras, a redução há-de permitir a subsistência do negócio, assegurar a manutenção do seu conteúdo (embora reduzido), nunca podendo, consequentemente, conduzir à descaracterização do tipo contratual. Ora, o efeito real da compra e venda não resulta de uma parte autonomizável do contrato que possa ser eliminada mantendo-se a parte restante (a referente aos efeitos obrigacionais), tal como se o efeito real fosse estabelecido numa cláusula autonomizável do negócio. Segundo o nosso entendimento, o contrato de compra e venda é uno, simultaneamente obrigacional e dispositivo, e, por isso, a invalidade decorrente do facto de a coisa ser alheia não pode afectar apenas os efeitos reais, não podendo, por isso, ser havida como meramente parcial.

Em resumo, não se pode admitir tal espécie de "redução", uma vez que a mesma conduziria a que se aceitasse que o negócio perdesse o seu elemento mais essencial - o efeito real -, envolvendo, assim, na nossa perspectiva, o "desaparecimento" do contrato de compra e venda.

Acrescente-se, ainda, que tal redução também não seria compatível com a previsão legal de convalidação do negócio. De facto, como é que o contrato poderia ser parcialmente válido, porque objecto de redução da parte viciada -, ou seja, da parte que visava produzir efeitos reais -, mas, depois, ser convalidado e ressurgir como contrato de compra e venda, caso fosse eliminado o vício que afectava a referida "parte real” previamente excluída?

${ }^{35}$ Que, acrescente-se, não acautela sequer o interesse das partes que demonstrem que o contrato não teria sido concluído sem a parte viciada 
Saliente-se, por fim, que na vigência do Código de Seabra a doutrina que se recusava a admitir a nulidade da venda de coisa alheia nunca afirmou a sua validade parcial, de facto, como já referimos, ou defendia que em causa estava um contrato válido mas resolúvel, ou um contrato que padecia de nulidade relativa - que correspondia à actual anulabilidade, não a nulidade parcial.

C) - Segundo CLARA SOTTOMAYOR, como referimos, o contrato de compra e venda de coisa alheia faz surgir, por si só, na esfera jurídica do alienante, a obrigação de convalidar o contrato ou de adquirir o direito ou a coisa e a obrigação de proceder à respectiva entrega, e, na esfera jurídica do adquirente, a obrigação de efectuar o pagamento ${ }^{36}$. Mais, segundo esta Autora, o contrato, parcialmente nulo, é susceptível de execução voluntária ou coerciva, por iniciativa do comprador de boa fé, desde que o verdadeiro proprietário não reivindique a coisa.

Nós, ao invés, consideramos que o reconhecimento de efeitos obrigacionais à venda civil de coisa alheia contraria a finalidade da norma que consagra a nulidade e o regime previsto na lei.

Vejamos com mais pormenor.

1) Quanto à obrigação que impende sobre o vendedor - quando o comprador esteja de boa fé de adquirir o direito vendido para, assim, sanar a nulidade da venda, ou convalidar o negócio (cfr. art. 897. ${ }^{\circ}$, n. ${ }^{\circ}$ 1, do Código Civil), vale o anteriormente afirmado, ou seja, e em resumo, para evitar repetições, não é um efeito essencial do contrato de compra e venda civil de coisa alheia, é, isso sim, uma consequência do vício do contrato e tem por fonte própria e directa a lei. Tanto assim é que o incumprimento da obrigação de sanar a nulidade da venda - imposta pelo art. $897 .^{\circ}$ do Código Civil - dá origem a uma obrigação de indemnização diversa daquela que resulta do facto de ter sido celebrado um contrato nulo ${ }^{37}$.

Acresce que, de acordo com o art. $903 .^{\circ}$ do Código Civil, o art. 897. ${ }^{\circ}$ do mesmo diploma legal, pode ser derrogado, mediante convenção das partes inserta no próprio contrato de compra e venda, desde que o vendedor não actue com dolo, consequentemente, pode não existir a obrigação de convalidação do contrato nulo, não obstante o comprador estar de boa fé.

\footnotetext{
${ }^{36}$ Como resulta do exposto, apesar de CLARA SOTTOMAYOR afirmar que a venda de coisa alheia é parcialmente nula e não apenas resolúvel, reconhece ao contrato mais efeitos obrigacionais do que YARA MIRANDA. De facto, relembramos, segundo esta Autora, da compra e venda de coisa alheia apenas emerge a obrigação de adquirir a coisa ou o direito e de, assim, convalidar o negócio.

${ }^{37}$ Por isso, segundo o nosso entendimento, após a convalidação, a aquisição da coisa ou do direito apenas produz efeitos ex nunc. A este propósito cumpre ainda lembrar que considerar o adquirente de coisa alheia, após a convalidação do negócio, como o verdadeiro titular do direito desde a data da celebração da compra e venda, além do mais, implica: reconhecer-lhe legitimidade para intentar acção tendente à reparação dos danos causados por um terceiro entre a data da compra e venda e a data da convalidação; imputar-lhe, em princípio, a responsabilidade pelos danos causados pela ruína do edifício ou de outra obra (cfr., por exemplo, o art. 492. ${ }^{\circ}$ do Código Civil); atribuir àquele, e não ao até ali proprietário da coisa, o direito de fruição entre a data da celebração do contrato de compra e venda de coisa alheia e a sua convalidação - não obstante, como é evidente, o até ali proprietário da coisa sempre ter a possibilidade de, ao abrigo do $1270 .^{\circ}$, n. $^{\circ} 1$, do Código Civil, fazer seus os frutos percebidos enquanto possuidor de boa fé.
} 
Assim sendo, admitir que a venda de coisa alheia é apenas parcialmente nula, mesmo quando tenha sido derrogada a obrigação de convalidação, é reconhecer a existência de um contrato de compra e venda quando é certo que este nunca virá a produzir efeitos reais. Ora, na nossa perspectiva, tal é inadmissível, uma vez que, quando ab initio, no momento da celebração do contrato, já está definitiva e irremediavelmente posta em causa a produção dos efeitos reais - não obstante o comprador o ignorar -, não vemos como se possa afirmar que em causa ainda está um contrato de compra e venda válido, mesmo que só parcialmente.

2) No que diz respeito à obrigação de entrega da coisa, na nossa perspectiva, ela não existe na esfera jurídica do vendedor em virtude da celebração do contrato de compra e venda de coisa alheia, apenas passando a existir quando ocorre a convalidação do mesmo - convalidação esta que depende sempre da colaboração do verdadeiro proprietário e que apenas opera, quando opera, ex nunc. Portanto, sendo a coisa alheia, enquanto assim permanecer, não há obrigação de entrega. Na verdade, o legislador não impõe a obrigação de entrega, mas sim a de convalidação; só depois de esta estar cumprida surge a obrigação de entrega. Nem podia ser de outra forma!

De facto, como é que o legislador poderia impor uma obrigação de entrega de uma coisa alheia? Por que razão a entrega da coisa poderia ocorrer voluntária e até coercivamente, independentemente da vontade do verdadeiro proprietário enquanto este não reivindicasse a coisa, quando se sabe que a acção de reivindicação é imprescritível? Como é que o Tribunal poderia condenar o vendedor a entregar a coisa pertencente a outrem, o mesmo é dizer, a realizar um acto legalmente impossível?

3) Por fim, entendemos que não existe qualquer obrigação, a cargo do comprador, de efectuar o pagamento, uma vez que a propriedade ainda não lhe foi transmitida (porque não pertencia e ainda não pertence ao vendedor) e não existe qualquer expectativa de que o venha a ser, uma vez que a obrigação de convalidação do contrato não pode ser cumprida contra a vontade e sem a colaboração do verdadeiro proprietário. Ou seja, no nosso ponto de vista, a obrigação de pagamento apenas surge, tal como a obrigação de entrega, se ocorrer a convalidação do contrato. Efectivamente, a que propósito imporia o legislador tal obrigação ao comprador, mesmo que de boa fé, fazendo-o correr o risco, não só de nunca vir a adquirir a coisa, mas, ainda, de não conseguir reaver o dinheiro entregue a título de pagamento?

Mais, sendo certo, na nossa perspectiva, que o vendedor não pode, legitimamente, efectuar a entrega da coisa, porque esta não lhe pertence, que sentido faria impor ao comprador a obrigação de efectuar o pagamento, quando a lei consagra a exceptio non adimplenti contractus (cfr. $\left.428 .^{\circ}\right)$ ? 
Por último, refira-se que a própria lei reconhece indirectamente a inexistência da obrigação de efectuar o pagamento antes da convalidação do contrato, ao estatuir que, caso tenha havido pagamento, o comprador de boa fé pode exigir a restituição e ainda tem direito a ser indemnizado (cfr. art. $\left.894 .^{\circ}\right)^{38}$.

D) - Segundo CLARA SOTTOMAYOR, o adquirente de boa fé é titular de um direito relativo, em virtude, precisamente, da sua boa fé. Direito relativo que, afirma, se apresenta como "uma figura próxima do direito de crédito, na medida em que consiste no poder de oposição, perante a invocação da nulidade do negócio, pelo alienante, e no poder de exigir, a este, a entrega da coisa, o cumprimento da obrigação de convalidação do contrato ou uma indemnização para a hipótese de incumprimento".

Não podemos concordar.

- Primeiro, porque não reconhecemos ao poder de oposição, perante a invocação da nulidade, a natureza de um direito relativo próximo do direito de crédito.

Explicitando.

Na nossa perspectiva, a lei limita-se a não reconhecer legitimidade ao vendedor para invocar procedentemente a nulidade, protegendo, deste modo, o comprador de boa fé. A lei não impõe ao vendedor qualquer dever jurídico de não invocar a nulidade. Se tal dever existisse, o vendedor poderia violá-lo e, portanto, obter a declaração de nulidade. Ora, tal não ocorre!

Assim, porque não existe um dever jurídico a cargo do vendedor de não invocar a nulidade, também o comprador de boa fé não é titular de qualquer direito correspectivo. Inexiste, portanto, qualquer relação jurídica, próxima de uma relação creditícia, por força da qual ao comprador seja atribuído o poder de exigir que o vendedor não invoque a nulidade do negócio. Na verdade, caso o vendedor venha a arguir, ilegitimamente, a nulidade, entendemos que o comprador de boa fé apenas tem a possibilidade de invocar uma excepção peremptória. Não mais! Em resumo, o legislador ao não atribuir legitimidade ao vendedor para invocar a nulidade, perante o comprador de boa fé, não pretendeu estabelecer entre eles qualquer relação intersubjectiva.

- Segundo, porque, como referimos, antes da convalidação, o vendedor não está obrigado a entregar a coisa alheia ou, noutra perspectiva, o comprador de boa fé não é titular do direito à entrega da coisa. $\mathrm{O}$ mesmo é dizer que, o direito à entrega da coisa só surge na esfera jurídica

\footnotetext{
${ }^{38}$ No entanto, é evidente que os princípios gerais, expressos no art. $289 .^{\circ}$, sobre os efeitos da nulidade, são, em certa medida, afastados pelo art. 894. ${ }^{\circ}$ quando o comprador tenha agido de má fé, isto é, com conhecimento de que a coisa era alheia, uma vez que, nesse caso, não pode, por argumento a contrario, pedir a restituição integral do preço, tendo apenas o direito de pedir, com base nos arts. $473 .^{\circ}$ e seguintes, aquilo com que o vendedor se locupletou.
} 
do comprador quando este já é proprietário dela, porque o negócio já deixou de ser inválido e já ocorreu a transmissão do direito real, ou seja, num momento em que a nulidade já não pode ser arguida por quem quer que seja. Em suma, o período de tempo durante o qual o vendedor não pode arguir a nulidade da venda, não coincide nunca com aquele durante o qual o comprador tem direito a que lhe seja entregue a coisa. Assim, na esfera jurídica do comprador nunca coexistem o poder de se opor à invocação da nulidade por parte do comprador e o direito à entrega da coisa.

- Terceiro, porque, não obstante impender sobre o vendedor, perante o comprador de boa fé, a obrigação de convalidar o negócio nulo - obrigação esta que, como já diversas vezes referimos, na nossa opinião, tem por fonte própria e directa apenas a lei -, o seu cumprimento depende da colaboração do verdadeiro proprietário. Consequentemente, apesar de o comprador de boa fé ter direito a ver convalidado o contrato, não pode exigir o seu cumprimento coactivo. De facto, se o proprietário se recusar a alienar o bem ao vendedor, nada mais restará ao comprador de boa fé do que o direito a ser indemnizado pelo incumprimento da obrigação de convalidação. - Quarto, porque, como já o dissemos, o direito a ser indemnizado pela não convalidação do contrato não decorre do facto de ter sido celebrado um contrato nulo - cuja nulidade não pode ser invocada pelo vendedor -, ou de forma mais abreviada, não é um efeito do contrato, é, isso sim, uma consequência decorrente do não cumprimento da obrigação de convalidação imposta por lei. Em face do exposto, podemos concluir que é a lei que é a fonte do poder do comprador de se opor, através de uma excepção peremptória, à arguição da nulidade por parte do vendedor, bem como, do direito a ser indemnizado pela celebração de um contrato nulo, do direito a ser ressarcido pelos danos decorrentes do não cumprimento da obrigação de convalidação ${ }^{39}$. Por seu turno, o direito à entrega da coisa decorre da convalidação do contrato.

E) - No nosso ordenamento jurídico são muito frequentes os desvios ao regime estatuído nos arts. $286 .^{\circ}$ a $294 .^{\circ}$, sendo comuns, portanto, as nulidades e anulabilidades atípicas ${ }^{40}$.

\footnotetext{
${ }^{39}$ Recordamos, ainda, que, de acordo com o art. $903 .^{\circ}$ do Código Civil, o art. $897 .^{\circ}$ e o art. $900 .^{\circ}$ (do mesmo diploma legal) podem ser derrogados, mediante convenção das partes, desde que o vendedor não actue com dolo. Consequentemente, não obstante o comprador estar de boa fé pode nem sequer ter o direito à convalidação do contrato nulo e, consequentemente, o direito a ser indemnizado em caso de não convalidação do contrato, bem como, não obstante poder ser titular do direito à convalidação do contrato, não ter o direito a ser indemnizado em caso de não convalidação.

Saliente-se, por fim, que as convenções previstas nos $\mathrm{n}^{\mathrm{os}} .1 .^{\circ} \mathbf{e} 2 .^{\circ}$ do art. $903 .^{\circ}$ do Código Civil supõem que os contraentes previram a possibilidade de a venda ser nula - por a coisa vendida não pertencer ao vendedor - e, por isso, estabeleceram um regime diferente do resultante da lei, mas não implicam, como é evidente, a má fé ou o dolo dos contraentes. De facto, o legislador, ao admitir a derrogação do regime legal da compra e venda de coisa alheia, partiu do pressuposto de que a simples previsão de que a venda pode ser nula não destrói a boa fé dos contraentes, uma vez que todos os preceitos que podem ser derrogados supõem a boa fé de um dos estipulantes.

${ }^{40}$ Cfr. ALARCÃO, RUI DE, Sobre a invalidade do negócio jurídico, in Estudos em Homenagem ao Prof. Doutor J. J. Teixeira Ribeiro, II I, Boletim da Faculdade de Direito, Coimbra, p. 620).
} 
JARDIM, Mónica Vanderleia Alves de Souza. A venda de coisa alheia como própria, em Portugal

Por todo o exposto, reafirmamos, consideramos que a venda de coisa alheia, não obstante estar sujeita a um regime atípico, é totalmente nula.

\section{Referências}

ALARCÃO, RUI DE. Sobre a invalidade do negócio jurídico. In: Estudos em Homenagem ao Prof. Doutor J. J. Teixeira Ribeiro, II I, Boletim da Faculdade de Direito, Coimbra.

ALMEIDA, CARLOS FERREIRA DE. Transmissão contratual da propriedade - Entre o mito da consensualidade e a realidade de múltiplos regimes. Themis, Ano VI, n. 11, 2005.

CABRAL, AMARAL. Venda de Coisa Alheia, Coimbra, 1956.

CORDEIRO, MENEZES. Da Boa. Fé no Direito Civil. Coimbra, Almedina, 1997.

CUNHA, PAULO OLAVO. Venda de bens alheios. Revista da Ordem dos Advogados, 1987.

GONÇALVES, LUIZ DA CUNHA. Tratado do direito civil em comentário ao código civil português. vol. III. Coimbra: Coimbra Editora, 1934.

JARDIM, MÓNICA. A incerteza gerada pelo registo, com efeito enunciativo, de um facto apenas eficaz inter partes. In: $\mathbf{O}$ contrato na gestão do risco e na garantia da equidade. MONTEIRO, António Pinto (coord.). Instituto Jurídico, Faculdade de Direito da Universidade de Coimbra.

JARDIM, MÓNICA. A actual problemática a propósito do princípio da consensualidade. Boletim da Faculdade de Direito, VOL. XC, T. I, Coimbra, 2014.

LIMA, PIRES DE / VARELA ANTUNES. Código Civil Anotado. vol. II, 5. ed. Coimbra, Coimbra Editora, 1997.

MARTINEZ, ROMANO. Direito das Obrigações (Parte Especial). Contratos. Compra e Venda. Locação. Empreitada. 2. ed. 2. reimp. Coimbra, Almedina, p. 117.

PROENÇA, BRANDÃO. A Resolução do contrato no direito civil- do enquadramento e do regime, reimp., Coimbra, Coimbra Editora, 2006.

TELLES, GALVÃO. Contratos civis - Projecto completo de um título do futuro Código Civil português e respectiva exposição de motivos. Separata da Revista da Faculdade de Direito da Universidade de Lisboa, vols. IX-X, 1953-1954, p. 158 e 159.

VENTURA, RAÚL. O contrato de compra e venda no Código Civil. Venda de bens alheios Venda com expedição. Revista da Ordem dos Advogados, 1980.

YARA MIRANDA. Venda de coisa alheia. Themis, Ano VI, n. ${ }^{\circ}$ 11, 2005. 